\title{
Urban Noise Exposure and Cardiometabolic Diseases: An Exploratory Cross-Sectional Study in Lisbon
}

\author{
Gonçalo Martins Pereira $^{a} \quad J_{\text {José Brito }}{ }^{a}$ Maria João Oliveirab Pedro Oliveira ${ }^{a}$ \\ ${ }^{a}$ Center for Interdisciplinary Research Egas Moniz (CiiEM), Monte da Caparica, Portugal; \\ bInstituto de Ciências Biomédicas Abel Salazar - ICBAS, Universidade do Porto, Porto, Portugal
}

\section{Keywords}

Urban noise - Diabetes mellitus · Hypertension - Obesity · Lisbon

\begin{abstract}
Introduction: Urban noise pollution has been associated with an increased risk of developing metabolic syndrome. Nevertheless, existing observational studies relating to noise exposure and metabolic syndrome are based on non-generalizable cohorts. Lisbon remains a noisy city where this association has not been evaluated, and for this reason, we studied the relationship between exposure to urban noise and the prevalence of type 2 diabetes mellitus, obesity, and hypertension. Methods: Diurnal, evening and nocturnal noise emission levels were obtained for each street in the city from the Lisbon noise map. After allocation of all roads to the respective parish of Lisbon, the noise emission for each parish was averaged for each day period. The number of adult patients with type 2 diabetes mellitus, obesity and hypertension in 2014, 2015 and 2016 in each parish of Lisbon was obtained from the Regional Health Administration of Lisbon and Tagus Valley. Prevalence as a percentage of the population was determined using the number of residents in each parish determined in the 2011 population census. Spear-
\end{abstract}

man's non-parametric correlation coefficient was used due to the non-normal distribution of the variables, at the $5 \%$ significance level $(a=0.05)$. Results: No correlations were found between daytime, afternoon or night-time noise exposure and the prevalence of type 2 diabetes mellitus, obesity or hypertension, although correlations were found between the cardiometabolic variables. Nevertheless, noise levels in Lisbon were above the legally established limit and the World Health Organization guidelines for environmental noise exposure in the European region. Conclusion: Our results do not agree with previous studies and should be faced as preliminary due to a strong biological plausibility for an association between noise exposure and cardiometabolic diseases and to encourage further studies, with longitudinal cohorts.

\section{(c) 2021 The Author(s). Published by S. Karger AG, Basel on behalf of NOVA National School of Public Health}

\section{Exposição a ruído urbano e doenças cardiometabólicas: um estudo transversal exploratório em Lisboa}

\section{Palavras Chave}

Ruído urbano - Diabetes mellitus - Hipertensão ·

Obesidade $\cdot$ Lisboa karger@karger.com www.karger.com/pjp

Karger $\stackrel{\text { ' }}{5}$

GOPEN ACCESS (c) 2021 The Author(s). Published by S. Karger AG, Basel on behalf of NOVA National School of Public Health

This is an Open Access article licensed under the Creative Commons Attribution-NonCommercial-4.0 International License (CC BY-NC) (http://www.karger.com/Services/OpenAccessLicense), applicable to the online version of the article only. Usage and distribution for commercial purposes requires written permission.
Correspondence to:

Gonçalo Martins Pereira, gpereira@ egasmoniz.edu.pt 


\section{Resumo}

Introdução: A poluição sonora urbana tem sido associada a um risco aumentado de desenvolver síndrome metabólica. No entanto, os estudos observacionais existentes que relacionam a exposição a ruído e a síndrome metabólica são baseados em coortes não generalizáveis. Lisboa continua a ser uma cidade ruidosa onde esta associação não foi avaliada, pelo que estudámos a relação entre a exposição ao ruído urbano e a prevalência de diabetes mellitus tipo 2, obesidade e hipertensão. Métodos: Os níveis diurnos, vespertinos e noturnos de emissão de ruído foram obtidos para cada rua da cidade a partir do mapa de ruído de Lisboa. Após atribuição das ruas à respetiva freguesia, procedeu-se ao cálculo da média das emissões sonoras de cada freguesia para cada período do dia. O número de doentes adultos com diabetes mellitus tipo 2, obesidade e hipertensão em 2014, 2015 e 2016 em cada freguesia foi obtido junto da Administração Regional de Saúde de Lisboa e Vale do Tejo. $O$ coeficiente de correlação não paramétrica de Spearman foi utilizado devido à distribuição não normal nas variáveis, ao nível de significância de $5 \%(a=0,05)$. Resultados: Não foram encontradas correlações entre a exposição ao ruído diurno, vespertino ou noturno e a prevalência de diabetes mellitus tipo 2, obesidade ou hipertensão, embora tenham sido encontradas correlações entre as variáveis cardiometabólicas. No entanto, os níveis de ruído em Lisboa situaram-se acima do limite legalmente estabelecido e das diretrizes da Organização Mundial de Saúde para a exposição ao ruído ambiente na região europeia. Conclusão: Os nossos resultados não concordam com estudos anteriores e devem ser encarados como preliminares devido a uma forte plausibilidade biológica para uma associação entre exposição ao ruído e doenças cardiometabólicas e para estimular novos estudos, com coortes longitudinais.

C 2021 The Author(s). Published by S. Karger AG, Basel on behalf of NOVA National School of Public Health

\section{Introduction}

Noise pollution has been increasing all over the world, mainly in urban environments [1], due to sources such as road, rail and air traffic [2]. Observational studies in these populations have associated noise exposure with negative effects that go beyond the auditory system [3], and longitudinal cohort studies have shown that noise pollution specifically increases the risk of developing metabolic syndrome [4-6].
Metabolic syndrome is a pathological condition that includes central obesity, insulin resistance (or type $2 \mathrm{di}$ abetes mellitus), hypertension and dyslipidaemia [7], in a complex interaction between individual genetic predisposition and environmental factors [8-10]. Observational studies in cities such as Stockholm and Toronto showed that noise exposure is associated with an increased risk of obesity, hypertension, diabetes and dyslipidaemia [6].

Due to the increased prevalence, morbidity and mortality of metabolic syndrome worldwide [11], particular attention has been paid to environmental determinants, namely noise, to counteract the epidemiological trend [12]. However, observational studies have been carried out in a small number of cities in countries such as Denmark, Sweden, Norway, Canada and the UK, having a limited external validity, as these have specific social, urban and demographic characteristics [6]. Thus, studies are relevant to estimate the association between exposure to urban noise and its cardiometabolic effects in different populations $[13,14]$.

Lisbon, the capital and largest city (and municipality) in Portugal, has a territory of about $85 \mathrm{~km}^{2}$ and a population of approximately 550,000 individuals, divided into 24 parishes [15]. The population of Lisbon is exposed to high levels of noise throughout the day, originating from road traffic, due to the high volume of daily passengers entering the city [16], as well as rail and air traffic, due to the high number of railway stations and the location of Lisbon airport on the outskirts of the municipality, just 5 $\mathrm{km}$ from the centre [16], and with the air corridor cutting the city in half.

This sound environment, characterised by excessive daytime and night-time noise, has changed little since 2008 despite the monitoring and intervention programmes on urban noise in the city of Lisbon, placing Portugal and in particular the city of Lisbon in a very unfavourable situation in terms of noise levels under European air traffic legislation, according to the European Environment Agency [16]. Lisbon is the second-worst rated European capital regarding exposure to air traffic noise, in terms of the Lden indicator (average of $24 \mathrm{~h}$ weighted by day, evening and night periods), with $15 \%$ of the population in Lisbon municipality exposed to levels above 55 $\mathrm{dB}$, and in terms of the Ln indicator (night noise between 11 p.m. and 7 a.m.), with $10 \%$ of the population exposed to levels above $50 \mathrm{~dB}$ [16].

To the best of our knowledge, there are no studies that verify the relationship between noise exposure and metabolic syndrome in the city of Lisbon. Therefore, we car- 


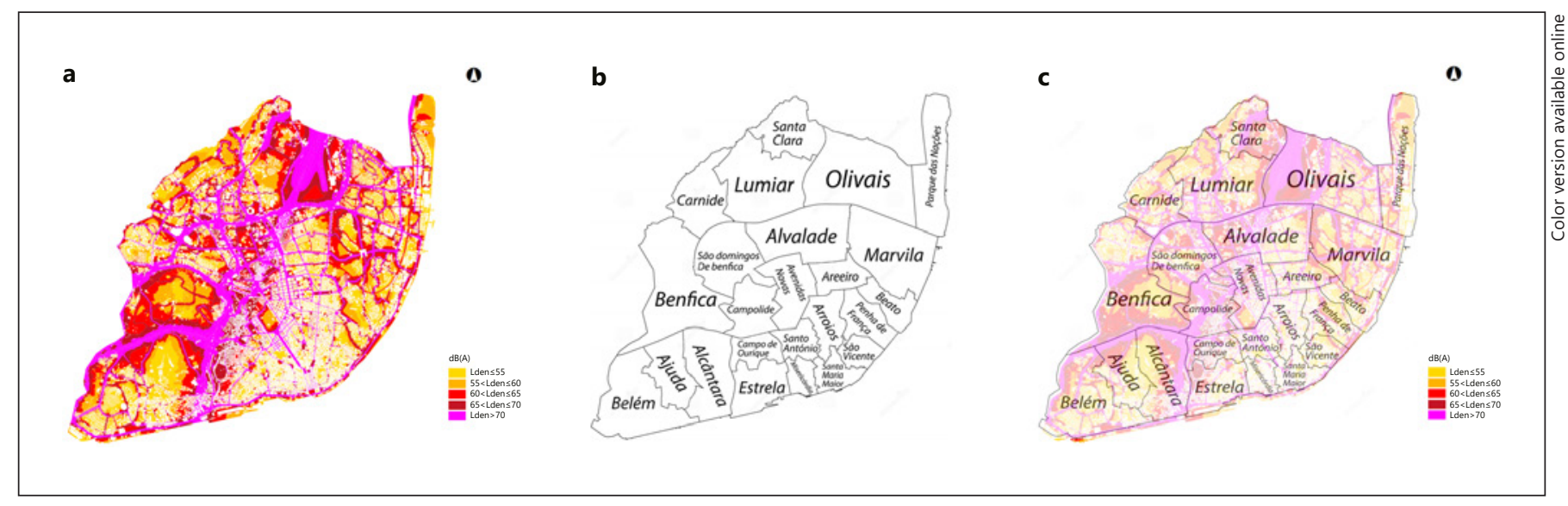

Fig. 1. a Lisbon noise map in 2008 showing the estimated noise exposure for the combined diurnal, evening and nocturnal emissions (adapted from [15]). b Outline of the boundaries of each parish in Lisbon (retrieved from [54]). c Lisbon noise map in 2008 with the outline of the boundaries of each parish in Lisbon (adapted from [15, 54]).

ried out an exploratory cross-sectional study to evaluate the association between exposure to urban noise and the prevalence of type 2 diabetes mellitus, obesity and hypertension in Lisbon.

\section{Materials and Methods}

Study protocol and data provision were approved by the Ethics Committee of the Regional Health Administration of Lisbon and Tagus Valley, IP (ref. 1723/CES/2017). The association between the different variables was verified at the level of each of the 24 parishes ("freguesias") of the city of Lisbon: Ajuda, Alcântara, Alvalade, Areeiro, Arroios, Avenidas Novas, Beato, Belém, Benfica, Campo de Ourique, Campolide, Carnide, Estrela, Lumiar, Marvila, Misericórdia, Olivais, Parque das Nações, Penha de França, Santa Clara, Santa Maria Maior, Santo António, São Domingos de Benfica and São Vicente.

\section{Urban Noise Exposure in Lisbon}

European Directive 2002/49/CE and Portuguese legislation (Decree-Law 146/2006) instructed municipalities to draw up noise maps to assess noise emissions from the road, air and rail traffic in three reference periods - day, evening and night. Since 2008, the municipality of Lisbon has publicly released its noise map, drawn up following legally established criteria (shown in Fig. 1). A detailed description of the development of these noise maps can be found elsewhere [17]. More recent noise maps have shown that noise levels in Lisbon have been similar throughout the years [15].

For the distribution of noise levels across the 24 parishes of Lisbon, measurements of noise emissions from the 2008 Lisbon noise map were considered for the three reference periods, obtained in the various streets of the city. Each street was assigned to the respective parish, and if a street crossed two adjacent parishes, it was assigned to both. After all streets were allocated, the average noise emissions for each parish were calculated for each reference peri- od. The mean values and standard deviations of noise emission from each parish and reference period are shown in Table 1.

\section{Prevalence of Type 2 Diabetes Mellitus, Obesity and}

Hypertension in Lisbon

Data were obtained from the Regional Health Administration of Lisbon and Tagus Valley on the number of adult patients with type 2 diabetes mellitus (identified by the International Classification of Primary Care [ICPC] code T90), obesity (ICPC code T82), uncomplicated hypertension (ICPC code K86) and complicated hypertension (ICPC code K87) in 2014, 2015 and 2016 for each parish in the municipality of Lisbon. To calculate prevalence as a percentage of the population for each parish and each year, the population of each parish of Lisbon in the 2021 census [18] was subtracted from the corresponding data in the 2011 census [18] to obtain the estimated population variation for each parish and each year between 2011 and 2021 (online suppl. material, see www. karger.com/doi/10.1159/000520263). As such, the estimated population of each parish in the city of Lisbon in 2014, 2015 and 2016 was obtained (online suppl. material) and prevalence as a percentage of the population was calculated. The prevalence of type 2 diabetes mellitus, obesity, uncomplicated and complicated hypertension in 2014, 2015 and 2016 for each parish is shown in Table 2.

\section{Statistical Analysis}

The non-parametric Spearman's rank correlation coefficient was used for data analysis using type 2 diabetes mellitus, obesity, uncomplicated and complicated hypertension prevalence in 2014, 2015 and 2016 and diurnal, evening and nocturnal noise emissions for each civil parish as variables. This test was used because deviation from a normal distribution was significant $(p=0.008)$ for nocturnal noise and strongly suggested $(p=0.059)$ for evening noise, as shown by the Shapiro-Wilk test of normality. As a surrogate analysis, the parametric Pearson correlation coefficient was also computed for the same associations. The analysis was performed using the IBM SPSS Statistics for Windows software, version 26 (IBM Corp., Armonk, NY, USA), at a significance level of $5 \%(\alpha=0.05)$. 
Table 1. Mean values and standard deviations of noise emission ( $\mathrm{dBA}$ ) in each parish of Lisbon for each reference period (diurnal, evening and nocturnal)

\begin{tabular}{llll}
\hline Civil parish & Diurnal, dBA & Evening, dBA & Nocturnal, dBA \\
\hline Ajuda & $81.29 \pm 2.09$ & $79.77 \pm 2.00$ & $72.96 \pm 1.91$ \\
Alcântara & $86.16 \pm 1.90$ & $85.25 \pm 1.96$ & $80.23 \pm 2.02$ \\
Alvalade & $84.00 \pm 2.10$ & $82.41 \pm 1.85$ & $75.52 \pm 1.59$ \\
Areeiro & $80.99 \pm 2.03$ & $79.15 \pm 1.90$ & $72.69 \pm 1.77$ \\
Arroios & $79.98 \pm 2.21$ & $78.23 \pm 2.13$ & $72.22 \pm 2.05$ \\
Avenidas Novas & $80.29 \pm 1.69$ & $78.77 \pm 1.78$ & $72.49 \pm 1.88$ \\
Beato & $80.65 \pm 1.74$ & $79.14 \pm 1.99$ & $72.64 \pm 2.24$ \\
Belém & $83.80 \pm 1.82$ & $81.70 \pm 1.73$ & $75.14 \pm 1.64$ \\
Benfica & $83.73 \pm 1.89$ & $81.89 \pm 1.84$ & $75.43 \pm 1.79$ \\
Campo de Ourique & $81.25 \pm 1.91$ & $79.48 \pm 1.94$ & $72.91 \pm 1.97$ \\
Campolide & $85.36 \pm 1.67$ & $84.54 \pm 1.86$ & $79.33 \pm 2.04$ \\
Carnide & $84.45 \pm 2.11$ & $83.07 \pm 2.02$ & $76.73 \pm 1.92$ \\
Estrela & $82.82 \pm 1.93$ & $80.96 \pm 2.03$ & $74.48 \pm 2.12$ \\
Lumiar & $86.49 \pm 2.05$ & $85.52 \pm 1.85$ & $80.42 \pm 1.65$ \\
Marvila & $82.37 \pm 1.99$ & $80.60 \pm 1.96$ & $74.14 \pm 1.93$ \\
Misericórdia & $81.97 \pm 1.78$ & $80.22 \pm 1.82$ & $74.15 \pm 1.86$ \\
Olivais & $82.48 \pm 1.65$ & $80.58 \pm 1.75$ & $74.10 \pm 1.84$ \\
Parque das Nações & $82.21 \pm 2.23$ & $80.10 \pm 1.99$ & $73.62 \pm 1.75$ \\
Penha de França & $79.17 \pm 1.87$ & $77.64 \pm 1.78$ & $71.17 \pm 1.68$ \\
Santa Clara & $86.92 \pm 2.04$ & $86.52 \pm 2.13$ & $82.34 \pm 2.22$ \\
Santa Maria Maior & $81.17 \pm 1.79$ & $78.32 \pm 1.92$ & $72.23 \pm 2.04$ \\
Santo António & $80.60 \pm 1.58$ & $78.53 \pm 1.85$ & $72.93 \pm 2.11$ \\
São Domingos de Benfica & $85.69 \pm 2.01$ & $84.86 \pm 1.97$ & $79.24 \pm 1.92$ \\
São Vicente & $79.21 \pm 1.92$ & $77.56 \pm 1.99$ & $70.98 \pm 2.07$ \\
\hline & & & \\
\hline
\end{tabular}

\section{Results}

Noise levels in Lisbon decreased throughout the day, with the lowest values observed at night (as shown in $\mathrm{Ta}$ ble 1). The noisiest parish in the city of Lisbon for all reference periods was "Santa Clara."

No correlations were found between diurnal, evening or nocturnal noise exposure and the prevalence of type 2 diabetes mellitus, obesity or hypertension in any of the studied years (shown in Table 3 ). The magnitude and significance of these associations were essentially the same using the Pearson correlation coefficient. Consistent correlations were found between the prevalence of type 2 diabetes mellitus, obesity, uncomplicated and complicated hypertension throughout the studied years, as shown in Table 4.

\section{Discussion}

Our study aimed to investigate a possible cross-sectional association between exposure to urban noise and the prevalence of type 2 diabetes mellitus, obesity and hypertension in the city of Lisbon. We found no association between the considered factors, unlike other studies where authors found an increased risk of cardiometabolic diseases in populations exposed to noise [1926].

There is a strong biological plausibility for an association between noise exposure, type 2 diabetes mellitus, obesity and hypertension. Noise exposure acts as a physiological and psychological stressor, activating the neuroendocrine pathways, such as the hypothalamus-pituitaryadrenal axis and the sympathetic nervous system, with subsequent release of cortisol and catecholamines [27]. Long-term noise exposure leads to chronic hypercortisolism and hyperglycaemia and, as such, promotes hyperinsulinism, insulin resistance, dyslipidaemia, central adiposity, endothelial dysfunction, oxidative stress, inflammation and thrombotic predisposition [28-30], which lead to the development of type 2 diabetes mellitus, obesity and hypertension $[31,32]$. These effects are particularly pronounced with exposure to nocturnal noise. Nocturnal noise exposure can decrease sleep duration, reduce sleep quality and disrupt circadian rhythm, which is strongly and independently associated with adverse metabolic effects such as obesity and type 2 diabetes mellitus [33-35].

Our study found high levels of diurnal, evening and nocturnal noise in Lisbon. These noise levels were above 
Table 2. Prevalence of type 2 diabetes mellitus, obesity, uncomplicated and complicated hypertension in 2014,2015 and 2016 for each parish in Lisbon

\begin{tabular}{|c|c|c|c|c|c|c|c|c|c|c|c|c|}
\hline Parish & $\begin{array}{l}\text { DM2 } \\
2014\end{array}$ & $\begin{array}{l}\text { DM2 } \\
2015\end{array}$ & $\begin{array}{l}\text { DM2 } \\
2016\end{array}$ & $\begin{array}{l}\text { Obesity } \\
2014\end{array}$ & $\begin{array}{l}\text { Obesity } \\
2015\end{array}$ & $\begin{array}{l}\text { Obesity } \\
2016\end{array}$ & $\begin{array}{l}\text { HTA } \\
\text { nC } \\
2014\end{array}$ & $\begin{array}{l}\text { HTA } \\
\text { nC } \\
2015\end{array}$ & $\begin{array}{l}\text { HTA } \\
\text { nC } \\
2016\end{array}$ & $\begin{array}{l}\text { HTA } \\
\text { Comp } \\
2014\end{array}$ & $\begin{array}{l}\text { HTA } \\
\text { Comp } \\
2015\end{array}$ & $\begin{array}{l}\text { HTA } \\
\text { Comp } \\
2016\end{array}$ \\
\hline Alcântara & 4.6 & 7.5 & 7.6 & 1.4 & 4.5 & 5.1 & 12.2 & 20.8 & 20.9 & 1.1 & 3.3 & 3.6 \\
\hline Alvalade & 5.1 & 5.2 & 5.1 & 4.5 & 4.9 & 5.4 & 15.7 & 15.9 & 15.4 & 2.3 & 2.4 & 2.6 \\
\hline Areeiro & 3.8 & 4.1 & 4.1 & 2.9 & 3.6 & 4.2 & 10.9 & 11.6 & 12.0 & 1.6 & 1.7 & 1.8 \\
\hline Beato & 3.4 & 6.9 & 7.1 & 4.5 & 10.8 & 12.5 & 9.5 & 19.8 & 19.6 & 1.0 & 3.2 & 3.5 \\
\hline Belém & 2.4 & 4.0 & 4.2 & 0.9 & 2.9 & 3.3 & 7.8 & 13.7 & 14.1 & 1.0 & 2.3 & 2.8 \\
\hline Benfica & 8.2 & 7.8 & 8.0 & 9.0 & 9.6 & 10.7 & 24.4 & 23.7 & 24.0 & 4.9 & 4.7 & 5.2 \\
\hline Campo de Ourique & 6.0 & 6.0 & 6.0 & 7.7 & 8.8 & 9.2 & 19.4 & 19.6 & 19.4 & 3.6 & 4.0 & 4.1 \\
\hline Campolide & 6.3 & 6.6 & 6.7 & 5.0 & 5.7 & 6.1 & 17.4 & 18.0 & 18.0 & 2.9 & 3.2 & 3.2 \\
\hline Carnide & 5.7 & 5.8 & 5.9 & 7.4 & 8.3 & 8.7 & 16.7 & 17.0 & 17.2 & 3.1 & 3.0 & 3.2 \\
\hline Estrela & 4.4 & 4.5 & 4.5 & 2.1 & 2.5 & 3.0 & 16.1 & 16.3 & 16.3 & 1.6 & 1.8 & 1.8 \\
\hline Parque das Nações & 2.4 & 1.6 & 1.4 & 9.9 & 7.4 & 7.2 & 3.8 & 3.8 & 3.9 & 1.2 & 0.8 & 0.7 \\
\hline Penha de França & 4.7 & 6.7 & 6.7 & 0.7 & 0.8 & 1.0 & 14.7 & 20.2 & 19.8 & 1.5 & 2.9 & 3.1 \\
\hline Santa Clara & 4.5 & 4.8 & 4.9 & 3.5 & 4.0 & 4.5 & 10.4 & 11.2 & 11.7 & 1.6 & 1.8 & 1.9 \\
\hline Santa Maria Maior & 6.7 & 6.9 & 6.9 & 3.4 & 4.7 & 7.2 & 15.6 & 16.6 & 17.1 & 1.1 & 1.2 & 1.3 \\
\hline Santo António & 5.1 & 5.3 & 5.4 & 4.7 & 5.8 & 6.2 & 15.9 & 16.3 & 16.5 & 2.1 & 2.4 & 2.5 \\
\hline São Domingos de Benfica & 5.0 & 5.3 & 5.4 & 5.1 & 5.7 & 6.2 & 16.2 & 16.5 & 16.8 & 3.0 & 3.1 & 3.2 \\
\hline São Vicente & 5.0 & 6.5 & 6.5 & 3.1 & 5.8 & 6.3 & 12.2 & 17.5 & 17.4 & 1.9 & 3.0 & 3.2 \\
\hline
\end{tabular}

Values are presented as a percentage of the population (\%). DM2, type 2 diabetes mellitus; HTA, hypertension; nC, non-complicated; Comp, complicated.

Table 3. Spearman's correlation coefficient $\left(r_{s}\right)$ and its significance $(p)$ between diurnal, evening and nocturnal noise emissions and prevalence of type 2 diabetes mellitus, obesity, uncomplicated and complicated hypertension in 2014, 2015 and 2016 in the 24 civil parishes of Lisbon

\begin{tabular}{|c|c|c|c|c|c|c|c|c|c|c|c|c|c|}
\hline Evening (dBA) & $\begin{array}{l}r_{\mathrm{s}} \\
p\end{array}$ & $\begin{array}{l}0.000 \\
0.998\end{array}$ & $\begin{array}{l}-0.092 \\
0.668\end{array}$ & $\begin{array}{l}-0.058 \\
0.787\end{array}$ & $\begin{array}{l}0.231 \\
0.278\end{array}$ & $\begin{array}{l}0.001 \\
0.995\end{array}$ & $\begin{array}{l}-0.068 \\
0.751\end{array}$ & $\begin{array}{l}0.128 \\
0.550\end{array}$ & $\begin{array}{l}-0.053 \\
0.806\end{array}$ & $\begin{array}{l}-0.055 \\
0.799\end{array}$ & $\begin{array}{l}0.173 \\
0.420\end{array}$ & $\begin{array}{l}0.166 \\
0.439\end{array}$ & $\begin{array}{l}0.160 \\
0.456\end{array}$ \\
\hline
\end{tabular}

DM2, type 2 diabetes mellitus; HTA, hypertension; nC, non-complicated; Comp, complicated.

the legally established limit (Decree-Law 146/2006), which define an exposure limit value of $65 \mathrm{~dB}$ for daytime noise and $55 \mathrm{~dB}$ for nocturnal noise, and the recent World Health Organization guidelines for environmental noise in the European region [36]. Although we did not find a correlation between the factors, these high noise levels observed throughout the day could lead to an increase in negative cardiovascular and metabolic health outcomes in the future [37].

Analysing our results, it is important to consider that there is a significant number of daily commuters in Lisbon that are exposed to daily noise levels of this city but, 
Table 4. Spearman's correlation coefficient $\left(r_{s}\right)$ and its significance $(p)$ between prevalence of type 2 diabetes mellitus and obesity, uncomplicated and complicated hypertension in 2014, 2015 and 2016 in the 24 civil parishes of Lisbon

\begin{tabular}{|c|c|c|c|c|c|c|c|c|c|c|}
\hline & & $\begin{array}{l}\text { Obesity } \\
2014\end{array}$ & $\begin{array}{l}\text { Obesity } \\
2015\end{array}$ & $\begin{array}{l}\text { Obesity } \\
2016\end{array}$ & $\begin{array}{l}\text { HTA } \\
\text { nC } \\
2014\end{array}$ & $\begin{array}{l}\text { HTA } \\
\text { nC } \\
2015\end{array}$ & $\begin{array}{l}\text { HTA } \\
\text { nC } \\
2016\end{array}$ & $\begin{array}{l}\text { HTA } \\
\text { Comp } \\
2014\end{array}$ & $\begin{array}{l}\text { HTA } \\
\text { Comp } \\
2015\end{array}$ & $\begin{array}{l}\text { HTA } \\
\text { Comp } \\
2016\end{array}$ \\
\hline DM2 2014 & $\begin{array}{l}r_{\mathrm{s}} \\
p\end{array}$ & $\begin{array}{l}0.433 \\
\mathbf{0 . 0 3 5}\end{array}$ & $\begin{array}{l}0.446 \\
\mathbf{0 . 0 2 9}\end{array}$ & $\begin{array}{l}0.529 \\
\mathbf{0 . 0 0 8}\end{array}$ & $\begin{array}{l}0.876 \\
\mathbf{0 . 0 0 0}\end{array}$ & $\begin{array}{l}0.625 \\
\mathbf{0 . 0 0 1}\end{array}$ & $\begin{array}{l}0.632 \\
\mathbf{0 . 0 0 1}\end{array}$ & $\begin{array}{l}0.597 \\
\mathbf{0 . 0 0 2}\end{array}$ & $\begin{array}{l}0.501 \\
\mathbf{0 . 0 1 3}\end{array}$ & $\begin{array}{l}0.463 \\
\mathbf{0 . 0 2 3}\end{array}$ \\
\hline DM2 2015 & $\begin{array}{l}r_{\mathrm{s}} \\
p\end{array}$ & $\begin{array}{l}0.210 \\
0.325\end{array}$ & $\begin{array}{l}0.496 \\
\mathbf{0 . 0 1 4}\end{array}$ & $\begin{array}{l}0.564 \\
\mathbf{0 . 0 0 4}\end{array}$ & $\begin{array}{l}0.593 \\
\mathbf{0 . 0 0 2}\end{array}$ & $\begin{array}{l}0.934 \\
\mathbf{0 . 0 0 0}\end{array}$ & $\begin{array}{l}0.938 \\
\mathbf{0 . 0 0 0}\end{array}$ & $\begin{array}{l}0.181 \\
0.398\end{array}$ & $\begin{array}{l}0.709 \\
\mathbf{0 . 0 0 0}\end{array}$ & $\begin{array}{l}0.703 \\
\mathbf{0 . 0 0 0}\end{array}$ \\
\hline DM2 2016 & $\begin{array}{l}r_{\mathrm{s}} \\
p\end{array}$ & $\begin{array}{l}0.215 \\
0.312\end{array}$ & $\begin{array}{l}0.511 \\
\mathbf{0 . 0 1 1}\end{array}$ & $\begin{array}{l}0.581 \\
\mathbf{0 . 0 0 3}\end{array}$ & $\begin{array}{l}0.584 \\
\mathbf{0 . 0 0 3}\end{array}$ & $\begin{array}{l}0.936 \\
\mathbf{0 . 0 0 0}\end{array}$ & $\begin{array}{l}0.944 \\
\mathbf{0 . 0 0 0}\end{array}$ & $\begin{array}{l}0.158 \\
0.460\end{array}$ & $\begin{array}{l}0.719 \\
\mathbf{0 . 0 0 0}\end{array}$ & $\begin{array}{l}0.722 \\
\mathbf{0 . 0 0 0}\end{array}$ \\
\hline
\end{tabular}

Statistically significant correlations are highlighted in bold. DM2, type 2 diabetes mellitus; HTA, hypertension; nC, non-complicated; Comp, complicated.

if diagnosed with any of the studied diseases, are counted in their respective residential municipality and not in Lisbon. Also, there can be a considerable difference between noise exposure assessments based on the residence and the noise exposure measured by the method we used, allocating streets that cross several parishes and that may have various sound intensities due to their large extension $[38,39]$.

The cross-sectional design does not allow the establishment of a causal inference between the studied cardiometabolic diseases and noise exposure [40], which may also constitute a limitation. The specific associations between residential transport noise and diabetes arise mainly from longitudinal studies, following up a large population-based cohort of residents in urban regions [41]. Interestingly, this association holds even after adjusting for environmental co-exposures, including traffic-related air pollutants [42-45]. Thus, our study was an exploratory pilot study and aimed to establish preliminary evidence for future studies [40]. This is particularly relevant if we consider that strong earlier evidence exists.

Considering hypertension and obesity, the evidence of a relationship with road traffic noise is quite robust and is dose-dependent [23-25, 46-52]. Although we did not find an association concerning these factors, we should take into account that the prevalence of the studied cardiometabolic diseases in each civil parish of Lisbon was based on electronic health records from primary care. This creates a selection bias, excluding people with difficult access to healthcare and people covered by private insurance [53].

In summary, no association was found between exposure to diurnal, evening and nocturnal noise exposure and the prevalence of type 2 diabetes mellitus, obesity and hypertension in Lisbon. These results highlight the need for further research on the cardiometabolic effects of exposure to urban noise in Lisbon, due to its possible harmful effects on human health.

\section{Conclusion}

No correlations were found between exposure to urban noise in Lisbon and the prevalence of cardiometabolic diseases in any of the studied years. Noise levels were above the legally established limit and the recommended environmental noise exposure by the World Health Organization. More studies are needed on the cardiometabolic effects of urban noise exposure in Lisbon, especially longitudinal cohort studies with better cardiometabolic disease data and characterization of noise exposure in each parish of the city of Lisbon.

\section{Acknowledgement}

The authors would like to thank Davide Menezes and Eng. Pedro Oliveira for all the help provided with the Lisbon noise map.

\section{Statement of Ethics}

This study protocol was reviewed and approved by the Ethics Committee of the Regional Health Administration of Lisbon and Tagus Valley, IP, approval number 1723/CES/2017. 


\section{Conflict of Interest Statement}

The authors have no conflicts of interest to declare.

\section{Funding Sources}

This research did not receive any funding from agencies in the public, commercial or not-for-profit sectors.

\section{Author Contributions}

G.M.P. designed the study, collected and interpreted data and drafted the manuscript. J.B. performed the statistical analysis and revised the manuscript. M.J.O. and P.O. designed the study, interpreted data and substantially revised the manuscript. All authors read and approved the final manuscript.

\section{Data Availability Statement}

All data generated or analysed during this study are included in this article and its supplementary material files. Further enquiries can be directed to the corresponding author.

\section{References}

1 Jhanwar D. Noise pollution: a review. J Environ Pollut Human Health. 2016;4(3):72-7.

2 Slabbekoorn H. Noise pollution. Curr Biol. 2019 Oct;29(19):R957-60.

3 Basner M, Babisch W, Davis A, Brink M, Clark C, Janssen S, et al. Auditory and nonauditory effects of noise on health. Lancet. 2014 Apr;383(9925):1325-32.

4 Huang T, Chan TC, Huang YJ, Pan WC. The association between noise exposure and metabolic syndrome: a longitudinal cohort study in Taiwan. Int J Environ Res Public Health. 2020 Jun;17(12):4236.

5 Yu Y, Paul K, Arah OA, Mayeda ER, Wu J, Lee E, et al. Air pollution, noise exposure, and metabolic syndrome - A cohort study in elderly Mexican-Americans in Sacramento area. Environ Int. 2020 Jan;134:105269.

6 Leal C, Chaix B. The influence of geographic life environments on cardiometabolic risk factors: a systematic review, a methodological assessment and a research agenda. Obes Rev. 2011 Mar;12(3):217-30.

7 Alberti KG, Eckel RH, Grundy SM, Zimmet PZ, Cleeman JI, Donato KA, et al.; International Diabetes Federation Task Force on Epidemiology and Prevention; Hational Heart, Lung, and Blood Institute; American Heart Association; World Heart Federation; International Atherosclerosis Society; International Association for the Study of Obesity. Harmonizing the metabolic syndrome: a joint interim statement of the International Diabetes Federation Task Force on Epidemiology and Prevention; National Heart, Lung, and Blood Institute; American Heart Association; World Heart Federation; International Atherosclerosis Society; and International Association for the Study of Obesity. Circulation. 2009 Oct;120(16):1640-5.

8 McCracken E, Monaghan M, Sreenivasan S. Pathophysiology of the metabolic syndrome. Clin Dermatol. 2018 Jan-Feb;36(1):14-20.

9 Xu H, Li X, Adams H, Kubena K, Guo S. Etiology of metabolic syndrome and dietary intervention. Int J Mol Sci. 2018 Dec;20(1):128.
10 Barroso I, McCarthy MI. The genetic basis of metabolic disease. Cell. 2019 Mar;177(1):14661.

11 Saklayen MG. The Global Epidemic of the Metabolic Syndrome. Curr Hypertens Rep. 2018 Feb;20(2):12.

12 Gorman S, Larcombe AN, Christian HE. Exposomes and metabolic health through a physical activity lens: a narrative review. J Endocrinol. 2021 Apr;249(1):R25-41.

13 Kempen EV, Casas M, Pershagen G, Foraster $\mathrm{M}$. WHO environmental noise guidelines for the European region: a systematic review on environmental noise and cardiovascular and metabolic effects: a summary. Int J Environ Res Public Health. 2018 Feb;15(2):379.

14 Münzel T, Miller MR, Sørensen M, Lelieveld J, Daiber A, Rajagopalan S. Reduction of environmental pollutants for prevention of cardiovascular disease: it's time to act. Eur Heart J. 2020 Nov;41(41):3989-97.

15 Municipal de Lisboa C. Plano de Ação de Ruído de Lisboa [Internet]. Lisboa: Câmara $\mathrm{Mu}$ nicipal de Lisboa; 2014 [cited Sep 27, 2021]. Available from: https://www.lisboa.pt/filead$\mathrm{min} /$ cidade_temas/ambiente/qualidade_ambiental/documentos/PlanoAcaoRuidoLisboa.pdf

16 European Environment Agency. Environmental noise in Europe 2020 [Internet]. Luxembourg: Publications Office of the European Union; 2020 [cited Jun 22, 2021]. Available from: https://op.europa.eu/en/publicationdetail/-/publication/ed51a8c9-6d7e11ea-b735-01aa75ed71a1/language-en

17 Municipal de Lisboa C. Mapa de ruído da cidade de Lisboa [Internet]. Lisboa: Câmara Municipal de Lisboa; 2009 [cited Dec 10, 2020]. Available from: http://1998-2013.amlisboa.pt/fileadmin/ASSEMBLEIA_MUNICIPAL/AML/Area_Reservada/Reunioes/Mandato_2009_2013/2011_09_13_10_SO/Proposta_530_2011_Anexos/1_17_mapa_ruido. pdf
18 Instituto Nacional de Estatística. Censos 2021 [Internet]. Lisboa: INE; 2021 [cited Sept 29, 2021]. Available from: https://www.ine.pt/ scripts/db_censos_2021.html

19 Dzhambov AM. Long-term noise exposure and the risk for type 2 diabetes: a meta-analysis. Noise Health. 2015 Jan-Feb;17(74):23-33.

20 Dendup T, Feng X, Clingan S, Astell-Burt T Environmental Risk Factors for Developing Type 2 Diabetes Mellitus: A Systematic Review. Int J Environ Res Public Health. 2018 Jan;15(1):78.

21 Zare Sakhvidi MJ, Zare Sakhvidi F, Mehrparvar AH, Foraster M, Dadvand P. Association between noise exposure and diabetes: A systematic review and meta-analysis. Environ Res. 2018 Oct;166:647-57.

22 Wang H, Sun D, Wang B, Gao D, Zhou Y, Wang N, et al. Association between noise exposure and diabetes: meta-analysis. Environ Sci Pollut Res Int. 2020 Oct;27(29):36085-90.

23 Fu W, Wang C, Zou L, Liu Q, Gan Y, Yan S, et al. Association between exposure to noise and risk of hypertension: a meta-analysis of observational epidemiological studies. J Hypertens. 2017 Dec;35(12):2358-66.

24 Dzhambov AM, Dimitrova DD. Residential road traffic noise as a risk factor for hypertension in adults: systematic review and metaanalysis of analytic studies published in the period 2011-2017. Environ Pollut. 2018 Sep;240:306-18.

25 Chen F, Fu W, Shi O, Li D, Jiang Q, Wang T, et al. Impact of exposure to noise on the risk of hypertension: A systematic review and meta-analysis of cohort studies. Environ Res. 2021 Apr;195:110813.

26 Rojas-Rueda D, Morales-Zamora E, Alsufyani WA, Herbst CH, AlBalawi SM, Alsukait R, et al. Environmental risk factors and health: an umbrella review of meta-analyses. Int J Environ Res Public Health. 2021 Jan;18(2):704.

27 Russell G, Lightman S. The human stress response. Nat Rev Endocrinol. 2019 Sep;15(9): $525-34$.
Urban Noise Exposure and

Cardiometabolic Diseases
Port J Public Health 2021;39:95-102

DOI: $10.1159 / 000520263$ 
28 Recio A, Linares C, Banegas JR, Díaz J. Road traffic noise effects on cardiovascular, respiratory, and metabolic health: an integrative model of biological mechanisms. Environ Res. 2016 Apr;146:359-70.

29 Münzel T, Sørensen M, Gori T, Schmidt FP, Rao X, Brook FR, et al. Environmental stressors and cardio-metabolic disease: part IImechanistic insights. Eur Heart J. 2017 Feb;38(8):557-64.

30 Hahad O, Prochaska JH, Daiber A, Muenzel T. Environmental noise-induced effects on stress hormones, oxidative stress, and vascular dysfunction: key factors in the relationship between cerebrocardiovascular and psychological disorders. Oxid Med Cell Longev. 2019 Nov;2019:4623109.

31 Galicia-Garcia U, Benito-Vicente A, Jebari S, Larrea-Sebal A, Siddiqi H, Uribe KB, et al. Pathophysiology of type 2 diabetes mellitus. Int J Mol Sci. 2020 Aug;21(17):6275.

32 Saxena T, Ali AO, Saxena M. Pathophysiology of essential hypertension: an update. Expert Rev Cardiovasc Ther. 2018 Dec;16(12):879-87.

33 Schmid SM, Hallschmid M, Schultes B. The metabolic burden of sleep loss. Lancet Diabetes Endocrinol. 2015 Jan;3(1):52-62.

34 Münzel T, Kröller-Schön S, Oelze M, Gori T, Schmidt FP, Steven S, et al. Adverse cardiovascular effects of traffic noise with a focus on nighttime noise and the new WHO Noise Guidelines. Annu Rev Public Health. 2020 Apr;41(1):309-28.

35 Allada R, Bass J. Circadian Mechanisms in Medicine. NEngl J Med. 2021 Feb;384(6):55061.

36 Sheppard A, Ralli M, Gilardi A, Salvi R. Occupational noise: auditory and non-auditory consequences. Int $\mathrm{J}$ Environ Res Public Health. 2020 Dec;17(23):E8963.

37 van Kamp I, Simon S, Notley H, Baliatsas C, van Kempen E. Evidence relating to environmental noise exposure and annoyance, sleep disturbance, cardio-vascular and metabolic health outcomes in the context of IGCB $(\mathrm{N})$ : a scoping review of new evidence. Int $J$ Environ Res Public Health. 2020 Apr;17(9):3016.
38 Gan WQ, McLean K, Brauer M, Chiarello SA, Davies HW. Modeling population exposure to community noise and air pollution in a large metropolitan area. Environ Res. 2012 Jul;116:11-6.

39 Ma J, Li C, Kwan MP, Kou L, Chai Y. Assessing personal noise exposure and its relationship with mental health in Beijing based on individuals' space-time behavior. Environ Int. 2020 Jun;139:105737.

40 Wang X, Cheng Z. Cross-sectional studies: strengths, weaknesses, and recommendations. Chest. 2020 Jul;158(1 1S):S65-71.

41 Clark C, Sbihi H, Tamburic L, Brauer M, Frank LD, Davies HW. Association of Longterm exposure to transportation noise and traffic-related air pollution with the incidence of diabetes: a prospective cohort study. Environ Health Perspect. 2017 Aug;125(8):087025.

42 Eze IC, Foraster M, Schaffner E, Vienneau D, Héritier H, Rudzik F, et al. Long-term exposure to transportation noise and air pollution in relation to incident diabetes in the SAPALDIA study. Int J Epidemiol. 2017 Aug;46(4): 1115-25.

43 Ohlwein S, Hennig F, Lucht S, Matthiessen C, Pundt N, Moebus S, et al. Indoor and outdoor road traffic noise and incident diabetes mellitus: results from a longitudinal German cohort study. Environ Epidemiol. 2019 Feb;3(1):e037.

44 Sørensen M, Andersen ZJ, Nordsborg RB, Becker T, Tjønneland A, Overvad K, et al. Long-term exposure to road traffic noise and incident diabetes: a cohort study. Environ Health Perspect. 2013 Feb;121(2):217-22.

45 Shin S, Bai L, Oiamo TH, Burnett RT, Weichenthal S, Jerrett $M$, et al. Association between road traffic noise and incidence of diabetes mellitus and hypertension in Toronto, Canada: a population-based cohort study. J Am Heart Assoc. 2020 Mar;9(6):e013021.

46 Pyko A, Eriksson C, Lind T, Mitkovskaya N, Wallas A, Ögren M, et al. Long-term exposure to transportation noise in relation to development of obesity: a cohort study. Environ Health Perspect. 2017 Nov;125(11):117005.
47 Christensen JS, Raaschou-Nielsen O, Tjønneland A, Overvad K, Nordsborg RB, Ketzel $\mathrm{M}$, et al. Road traffic and railway noise exposures and adiposity in adults: a cross-sectional analysis of the Danish Diet, Cancer, and Health Cohort. Environ Health Perspect. 2016 Mar;124(3):329-35.

48 Cramer J, Therming Jørgensen J, Sørensen M, Backalarz C, Laursen JE, Ketzel M, et al. Road traffic noise and markers of adiposity in the Danish Nurse Cohort: A cross-sectional study. Environ Res. 2019 May;172:502-10.

49 Oftedal B, Krog NH, Pyko A, Eriksson C, Graff-Iversen S, Haugen M, et al. Road traffic noise and markers of obesity - a populationbased study. Environ Res. 2015 Apr;138:14453.

50 Pyko A, Eriksson C, Oftedal B, Hilding A, Östenson CG, Krog NH, et al. Exposure to traffic noise and markers of obesity. Occup Environ Med. 2015 Aug;72(8):594-601.

51 Foraster M, Eze IC, Vienneau D, Schaffner E, Jeong A, Héritier $\mathrm{H}$, et al. Long-term exposure to transportation noise and its association with adiposity markers and development of obesity. Environ Int. 2018 Dec;121(Pt 1):87989.

52 Christensen JS, Raaschou-Nielsen O, Tjønneland A, Nordsborg RB, Jensen SS, Sørensen $\mathrm{T}$, et al. Long-term exposure to residential traffic noise and changes in body weight and waist circumference: a cohort study. Environ Res. 2015 Nov;143(Pt A):154-61.

53 Laranjo L, Rodrigues D, Pereira AM, Ribeiro RT, Boavida JM. Use of electronic health records and geographic information systems in public health surveillance of type 2 diabetes: a feasibility study. JMIR Public Health Surveill. 2016 Mar;2(1):e12

54 Dreamstime. Mapa branco das paróquias civis de Lisboa, Portugal [Internet]. Lisboa: Dreamstime; 2021 [cited Oct 3, 2021]. Available from: https://pt.dreamstime.com/mapabranco-das-par\%C3\%B3quias-civis-de-lisboa-portugal-simples-do-vetor-com-fronteiras-negras-e-nomes-image226760540 